DOI: https://dx.doi.org/10.24093/awej/vol12no3.30

\title{
Intercultural Activities in Teaching Foreign Languages: Modern Ukrainian Dimension
}

\author{
Tetiana Mykhailivna Korolova \\ Department of Translation, Theoretical and Applied Linguistics \\ Faculty of Foreign Languages \\ State institution "South Ukrainian National Pedagogical University named after K. D. \\ Ushynsky" Odesa, Ukraine

\section{Oleksandra Volodymyrivna Popova} \\ Department of Translation, Theoretical and Applied Linguistics \\ Faculty of Foreign Languages \\ State institution "South Ukrainian National Pedagogical University named after K. D. \\ Ushynsky" Odesa, Ukraine \\ Coressponding Author: alex-popova@ukr.net
}

Received: 6/17/2021

Accepted: 9/24/2021

Published: 9/29/2021

\section{Abstract}

The article covers the issues related to implementing intercultural events into teaching foreign languages to Ukrainian university students. Against the backdrop of the requirements set by the Bachelor Educational Programs learning outcomes, the main aim of this research is to investigate how the integration of international work and methodological tools of teaching foreign languages to Ukrainian students can contribute to their academic success. The significance of the study manifests itself through the analysis of the methodological background for successful teaching foreign languages to Ukrainian students under current transformed teaching/learning conditions. These questions are considered: How can culture-related activities contribute to learning foreign languages? What learning outcomes can students have? The authors used the context and research tools as follows: the methods of systemic and content-oriented analyses to analyze and generalize the theoretical bases for the topic under study, to systemize the results of the survey (education-based intercultural activities, students' learning outcomes); focused observation using the register as a tool for data collecting for two semesters each in six groups of second-year students majoring in Philology and Lingua Didactics at Ushynsky University. The authors presented a sum of main findings: contribution of the programs of distance-based academic mobility to the teaching/learning process; internationalization of the educational process; adaptation of a criterial corpus for assessing Ukrainian students' learning acquisitions in English, Chinese, Turkish, and Korean in terms of linguistic and cultural knowledge and skills. The article contains recommendations for English, Chinese, Turkish, and Korean online and offline classes.

Keywords: English, Chinese, Turkish, Korean, teaching foreign languages, Ukrainian students, crosscultural communication

Cite as: Korolova, T. M., \& Popova, O. V. (2021). Intercultural Activities in Teaching Foreign

Languages: Modern Ukrainian Dimension. Arab World English Journal, 12 (3) 432-449.

DOI: https://dx.doi.org/10.24093/awej/vol12no3.30 


\section{Introduction}

The current conditions of the COVID-19 pandemic have made teachers and students adapt to new forms of presenting and acquiring knowledge. As practice shows, the sphere of teaching languages is the one that was affected to a great extent since teaching/learning languages has positive results if interlocutors communicate eye-to-eye. In most cases, educational institutions provide students with online classes, depriving teachers and students of sharing vivid emotions. Many students lose motivation to learn foreign languages using new technologies that have practically substituted the traditional ones. Thus, teaching staff encounters a dilemma: how to organize curricular and extracurricular activities to interest learners in mastering their communicative competence and how to sustain learners' desire to study foreign languages online.

We believe that language and culture are inseparable. It means that culture-related knowledge facilitates mastering a foreign language. That is why we accent the significance of culture-related activities in the framework of learning foreign languages. The implementation of intercultural events into teaching foreign languages is always relevant and predetermined by the international liaisons between Ukraine and other countries of the world. It (the issue) proves the demand for the training of highly skilled linguistic cross-culture-cognizant specialists who can apply their learning acquisitions masterfully in profession-related spheres and display their cultural proficiency to participate in cross-cultural and intercultural communication successfully.

Thus, the main aim of this research is to investigate how the integration of international work and methodological tools of teaching foreign languages to Ukrainian students can contribute to their academic success. The realization of the set aim is possible if these objectives are fulfilled: 1) to analyze the content of normative education-related documents and programs in the sphere of teaching/learning foreign languages (English, Chinese, Turkish, and Korean); 2) to substantiate the necessity to internationalize education; 3) to specify a criterion-based construct for assessing Ukrainian students' acquisitions under current conditions.

\section{Research questions}

The study has been framed around the questions given below.

1. How can culture-related activities contribute to learning foreign languages?

2. What learning outcomes can students have under conditions of the pandemic?

\section{Literature Review}

The cultural approach to teaching/learning foreign languages has stimulated scholars to undertake relevant studies - to write reviews concerning these issues: • language through cultural values and cultural background through language (Farahmandian \& Shao, 2020; Larzén, 2005; Byram \& Morgan, 1994); • intercultural challenges, intracultural practices (Fernández \& Pérez Cañado, 2012); • language and intercultural communication (Peeters, 2015; God \& Zhang, 2019; Shin, Zohreh \& Chen, 2011; Bagui \& Adder, 2020); • culture-centered approaches in teaching/learning foreign languages (Naryatmojo, 2019; Al Ghafri, Audeh \& Al-Gadallah, 2019; Andayani \& Gilang, 2020; Chekal, Palii, Potapenko \& Andriiko, 2010; Popova, 2016; Byram \& Esarte-Sarries, 1991); • multiculturalism in the framework of learning foreign languages (Fox \& Diaz-Greenberg, 2016; Prodromou, 2012; Vez, 2011; Veettil, Binu \& Karthikeyan, 2020). Some scholars equate sociocultural, ethnographic, and lingua-cultural approaches alongside lingua- 
country studies with the pedagogical phenomenon cultural approach in teaching/learning foreign languages. Let us consider some of them.

The scholars, when reviewing an original novel, accented the significance of a social and cultural background transferred through language and ideology (Farahmandian \& Shao, 2020), but they did not specify the education technologies that might promote learners' acquisitions. Larzén (2005) studied a complex relationship between language and culture and how to overcome difficulties when learning a particular language. He believes that "on the one hand language is an integral part of the culture, but on the other hand it is an expression of culture" (p. 27). Other scholars, Byram and C. Morgan (1994) claimed that language teachers must be teachers of culture since language and culture are inseparable. Peeters (2015) never separated the concept "language" from the idea of culture. Thus, culture nourishes language and vice versa language enriches expressive means aimed at nominating cultural units, which is to be acknowledged in the framework of teaching foreign languages.

Interlocutors' awareness of ethnic specificities, socio-communicative skills, and positive, tolerant attitudes towards each other stimulate intercultural communication. Most scholars treat the term "ethnos" (Gr. "̌ $\theta v o \varsigma$ - people, society, group) as a historically formed stable community of people - a tribe, a nationality, a nation, that is, a social organism that functions through ethnically homogeneous marriages. Community members transfer language, culture, traditions, ethnic orientations to a new generation.

Byram was the founder of the ethnographic approach to learning foreign languages; he recommended that learners should study the culture of the country alongside the language. The basis for its implementation is students' immersion into the social medium of a particular ethnic group. Students may prove themselves as ethnologists through four methods of ethnography: observation, questionnaires, interviews, and surveys (Byram \& Esarte-Sarries, 1991). It should be noted that under today's pandemic conditions, learners can hardly cognize the ethnic mentality of native speakers when obtaining distance education, which may lead to cross-cultural misunderstanding.

God and Zhang (2019) mentioned that language barriers and cultural distance are the factors that hinder communication. The Chinese scholars shared how Chinese international students and local students can understand and experience intercultural communication. Fernández and Cañado (2012) discussed differences between native and non-native English teachers and their didactic behavior. The authors supported the idea of Content and Language Integrated Learning (CLIL) in Spain, which presupposes the teaching of subjects to students through a target language (a language different from their mother tongue). In other words, their approach facilitates bilingual intercultural education, which is also to be implemented when training would-be teachers at universities. Nevertheless, they ignored the part of extracurricular culture-related activities in teaching/learning foreign languages. Shin et al. (2011) characterized the role of culture in teaching English as an international language (EIL) and outlined sociocultural perspectives in the context of English-language teaching (ELT) textbooks. The researchers analyzed the cultural content of seven series of internationally distributed ELT textbooks and concluded that even though "cultural aspects were proportionally diverse in each textbook series, inner circle cultural content still dominates most of the textbooks; cultural 
presentation still largely remains at the traditional knowledge-oriented level and does not engage learners in deep levels of reflection" (Shin et al., 2011, p. 1). Unfortunately, none of the studies has been devoted to implementing intercultural education in socially restricted conditions like online education. Bagui and Adder (2020) studied students' intercultural clashes when learning English Literature due to their ignorance of the differences between cultures. They suggested that learners should be taught "to be more tolerant and empathetic when interacting directly or indirectly with speakers of other languages, identities, or cultures" (2020, p. 92). However, the authors did not give any recommendations on how to stimulate students' desire to learn the background of cultural differences.

Naryatmojo (2019) paid great attention to local culture, which reflects the life peculiarities of a particular society. In the author's viewpoint, a lack of local wisdom practices may cause challenges. Another gap to be taken into account is that cultural education, according to this theory, is not presented in the form of separate subjects. Therefore, culture education should penetrate other fields of education, the sphere of teaching/learning foreign languages, in particular.

Al Ghafri et al. (2019) shared the idea that in teaching/learning foreign languages, a teacher must be a facilitator, a counselor, or sometimes a parent to stimulate students' communication using up-to-date teaching methods, which enables them to express themselves, and ultimately reach a solution, the teacher observing it, encouraging his/her students. It should be mentioned that this kind of communication might become more efficient if teachers - native speakers are involved in it. Byram's (1997) model of Intercultural Communicative Competence seems to be one of the most famous models. Its component, Intercultural Competency, comprises five subcomponents, as follows:

"1) attitudes: curiosity and openness, readiness to suspend disbelief about other cultures and belief about one's own; 2) knowledge: knowledge of social groups and their products and practices in one's own country and in the interlocutor's country, and the general processes of societal and individual interaction; 3) skills of interpreting and relating: the ability to interpret a document or event from another culture, to explain it and relate it to documents or events from one's own; 4) skills of discovery and interaction: the ability to acquire new knowledge of a culture and cultural practices and the ability to operate knowledge, attitudes, and skills under the constraints of real-time communication; 5) critical cultural awareness: the ability to evaluate critically and based on explicit criteria, perspectives, practices, and products in one's own and other cultures and countries" (p. 60-61).

Bouslama and Benaissi (2018) correlated intercultural competence with handling interactions with culturally unlike people. Popova (2016) classified the determinants of the cultural approach to teaching/learning foreign languages in this way: - a cultural profile of the countries the language(s) of which is (are) studied; - nation-related cultural heritage; - ethno-mentality; - nation-marked socio-communication; - linguacultural background (Popova, 2016). The Ukrainian educators Chekal, Palii, Potapenko, and Andriiko (2010) believed that a constructive "communication - an adequate understanding of two participators of a communicative act - is impossible without knowing the country realities, without the communicants' awareness of the reality both in their native country and in the country the language of which they learn" (p. 238). 
The scholars grounded the need of the language-targeted and culture-centered (intercultural, cross-cultural, lingua-cultural) approaches in teaching foreign languages at secondary school, which requires a culture-oriented model of teaching language(s) as well as training future teachers of foreign languages (Chekal et al., 2010). As we can see, the culture-based knowledge and awareness alongside communicative skills to decode culture-related issues and use them while interacting with native speakers are the keynote aspects to be observed while teaching foreign languages.

Fox and Diaz-Greenberg (2016) and teacher education candidates were involved in the foreign/world language licensure programs in two different U.S. universities. Their goal was to find out how critical pedagogy and multicultural education can help meet the challenges that world language teachers experience in the teaching of culture. The researchers revealed the existing difficulties in integrating the cultural standard in foreign/second language teacher education programs and some of the challenges faced in its practical implementation. They asserted that cultural understanding and communication around the world could facilitate honest dialogue, cooperation across countries as well as open the values of others, which might transform global thinking (Fox \& Diaz-Greenberg, 2016). Prodromou (2012) distinguished four keynote hypotheses in teaching/learning foreign languages: 1) the importance of the cultural background; 2) the importance of the cultural foreground; 3) the importance of a cross-cultural understanding and multicultural diversity; 4) the importance of cross-cultural understanding and multicultural diversity. The scholar admitted that some practicing teachers oppose cross-cultural components in course design to target or local culture. Vez (2011) considered an intellectual environment where multilingualism and interculturality are stimuli for social enrichment and cultural development. The cited authors welcomed the idea of multilingual education in terms of efficient teaching/learning foreign languages. However, they did not offer ways of cultural adaptation within a multicultural education environment or interiorization outcomes in this respect. Veettil et al. (2020) described a multilingual society represented by the migrant Keralites who acquire two or three more new languages: English, Hindi, and Arabic (as a result of their living abroad). The authors expressed their concerns about language shift and its negative consequences, but they did not give any suggestions regarding the amicable co-existence of different languages and cultures within a particular society.

Thus, taking into account the above said, we are going to share our experience and illustrate how intercultural activities might facilitate students' academic success in learning English, Chinese, Turkish, and Korean.

\section{Methods}

\section{Research Design}

This action research is based on the premise that even though English, Chinese, Turkish, and Korean are non-related languages and their linguistic differences stipulate different approaches to teaching/learning them, intercultural activities contribute to students' academic success.

\section{Participants}

The sample consists of the students of the Faculty of Foreign Languages at the State institution "South Ukrainian National Pedagogical University named after K. D. Ushynsky" (Odesa, Ukraine). The study was carried out with a sample population composed of one (1) group of the 
second-year students majoring in English Translation Studies (19 students), one (1) group of the second-year students minoring in Chinese Translation Studies (23 students), one group (1) of the second-year students majoring in English Language and Literature (27 students), one group (1) of the second-year students majoring in Chinese Language and Literature (23 students), one group (1) of the second-year students majoring in Turkish Language and Literature (7 students), and one group (1) of students who learn Korean during extracurricular classes (10 students) from 2020 to 2021 (academic year). The total sample size was 109.

\section{Research Instrument}

The participants were offered to take part in a specially elaborated program aimed at developing their cultural competence: to get involved in curricular and extracurricular culture-related activities; to demonstrate their cultural awareness while organizing culture-related events; to be part of academic mobility programs. They were interviewed on the details of the experimental study. The participants confirmed their intention to contribute to the empirical research via Office 365 (TEAMS).

\section{Data Analysis}

The methods of systemic and content-oriented analyses enabled us to analyze and generalize the theoretical bases for the topic under study, to systemize the results of the survey (educationbased intercultural activities, students' learning outcomes). The study was based on focused observation using the register as a tool for data collecting for two semesters each in six groups of second-year students majoring in Philology and Linguodidactics. To see the students' learning outcomes while participating in culture-related activities, we employed simple observation giving the research insights. The students' academic outcomes were fixed in a register throughout this study. The students were trained in diverse language activities: listening comprehension, speaking (monological and dialogical speech), writing, and reading within curricular and extracurricular activities to demonstrate their academic acquisitions and failures. Based on the observed outcomes, the authors propose some remedial measures (recommendations) to prevent dealing with complicated linguistic problems.

\section{Findings}

It seems to be expedient to study the Ukrainian education standards and educational professionoriented programs which determine the content of education and students' learning outcomes.

The students involved in the activities under our focus major in two specialties: 035 Philology and 014 Secondary Education, both specialties dealing with foreign languages: English, Chinese, Turkish, Korean* (Korean is being launched as the major this year). Let us consider the higher education standards of Ukraine in this respect. At our institution of higher education, we obey these standards: the higher education standard ciphered 03 The Humanities, 035 Philology (First (Bachelor of Arts) Level, 2019; Second (Master) Level, 2019) and The Profession-related Standard for Teachers of General Secondary School (2020).

In the education standard 035 Philology (Bachelor Level, 2019), the general competences and learning outcomes comprise these referred to the topic of the study: - the abilities to store and increase culture values; - the skills to freely communicate on professional issues with specialists and non-specialists in state and foreign language (s) orally and in writing, to use them to organize effective intercultural communication; - the skills to cooperate with colleagues, 
representatives of other cultures and religions, supporters of different political views, etc. Furthermore, intercultural and mass communication in its oral and written forms is one of the objects of education within the standards aimed at Bachelor- and Master-course students majoring in Philology.

In compliance with The Profession-related Standard for Teachers of General Secondary School (2020) (coded 2320 - Teacher of General Secondary School), the general competences cover the culture-centered one alongside the civil, social, leadership-oriented, and business-based ones. Culture-centered competence is associated with the ability to show respect and appreciate the Ukrainian national culture, diversity, and multiculturalism in society; the ability to express national cultural identity; creative self-expression. On the other hand, emotional and ethical competences oblige a teacher to correctly and adequately deal with the diversity and uniqueness of different cultures existing in our society; to consider differences between people; to use specific strategies for preventing, overcoming, and transforming conflicts. Thus, we endeavor to cover culture-biased units, linguistic and lingua didactic particularities while elaborating educational profession-targeted programs.

The educational profession-targeted programs Translation (major - English, minor Chinese) (Derik, Savchenko \& Shapoval, 2020) and "Translation (major - Chinese, minor English). Popova, Korolova, and Stoianova (2020) intended for the future translators of English and Chinese are focused on their fundamental theoretical and practical training, translating and interpreting within the language pairs English $\leftrightarrow$ Ukrainian, Chinese $\leftrightarrow$ Ukrainian, and English $\leftrightarrow$ Chinese providing for the development of the translator's professional competence as well as his/her abilities to participate in cross-cultural communication successfully. Therefore, the syllabi of the designated educational programs include compulsory subjects (like Problems of Intercultural Communication, History of Ukrainian Culture, History of Ukraine, etc.), which enable students: - to practically use the knowledge of the history and culture of Ukraine, the People's Republic of China alongside the English speaking countries for organizing efficient cross-cultural communication and adequate translating; - to cooperate with colleagues and representatives of other cultures and religions, with supporters of different political views.

Another education-related vector of the activities provided by the Faculty of Foreign Languages at the State institution "South Ukrainian National Pedagogical University named after K. D. Ushynsky" (Odesa, Ukraine) concerns teacher training specificities. These educational profession-oriented programs help to guarantee a successful teaching/learning process at the bachelor level: 1) Secondary Education (Language and Literature (English) (2020); 2) Secondary Education (Language and Literature (Chinese, English) (2020); 3) Secondary Education (Language and Literature (Turkish, English) (2020); 4) Secondary Education (Language and Literature (Korean, English) (2021). Their primary focus is to develop students' linguistic and teaching competences, which are actualized through their abilities to combine scientific, theoretical, didactic, methodological components in teaching English, Chinese, Turkish, and Korean alongside foreign literature. The academic efficiency of the programs under consideration is warranted due to international liaison. Overseas specialists from Great Britain, the USA, the People's Republic of China, Turkey, and the Republic of Korea (South Korea) teach our students foreign (major and minor) languages (English, Chinese, Turkish, and Korean). As for the students, international students from Turkey, Turkmenistan, 
China, and the USA acquire education at the Faculty of Foreign Languages, whereas Ukrainian students take part in the programs of academic mobility in overseas universities. The internationalization of the teaching/learning process is evident. The educational programs are organized in the way, which facilitates the academic success in terms of their learning outcomes; to use the necessary scientific tools of philosophy, psychology, pedagogy, contributing to the development of general culture and socialization of the individual as well as their ethical values, to be more precise, through these subjects: English - major/minor, Chinese - major, Turkish major, Korea - major, History of Ukrainian Culture, History of Ukraine, etc. It should be noted that both professions - the translator/interpreter and the teacher of foreign languages presuppose the involvement in cross-cultural communication and international activities, which proves the necessity to internationalize the educational process under social demands and job descriptions.

Within current circumstances of world integration and globalization, most Ukrainian higher education institutions are involved in international activities connected with education, science, culture, and sport, which facilitates the internationalization process. We can assume that this is the internationalization of higher education that provides for a free exchange of academic knowledge and experience in the scientists' (scholars') community.

The Bologna process contributed to the academic integration of the European countries and the unification of requirements set to higher education syllabi and curricula. To our great regret, the Oriental countries did not chance to join this process at its very beginning, and this explains differences in European and Oriental education content and standards. Though, we can observe similarities in the leveling of their higher education: Bachelor and Master levels. This is why we can speculate on the unification and internationalization of curricula and syllabi in Europe and Asia. The facts as mentioned above allow us to define the internationalization of higher education in Ukraine as gradual systemic integration of international activities into the global educational space, which simultaneously facilitates the development of higher education establishments in science-related (research) and social activities.

Another process contributing to the internationalization of education is interiorization (French intériorisation - transition from outside to inside, from Latin interior - internal), which is often associated with "the building of internal structures of the human psyche through the assimilation of external social activities, appropriation of life experience, the evolvement of mental functions and development in general" (Popova, 2021, p. 104).

We can transform the content of this psychological phenomenon into the plane of the Foreign Languages Department of Ushynsky University (Odesa, Ukraine) and interpret it as a process of building a student's inner spiritual world, namely: his/her needs, interests, desires, evaluative judgments, experiences, attitudes, behavior through mastering educational activities alongside intercultural and cross-cultural communication (Popova, 2021). We can also confirm these learning outcomes: 1) sociocultural adaptation of a university student; 2) development of student's thinking, self-awareness, his/her motivation to study; 3) assimilation of new knowledge and social experience. 
It is expedient to note that the implementation of internationalization tasks, as an essential component of international work at the Faculty of Foreign Languages; the involvement of the education and information centers of other countries into this activity; the organization of interaction with foreign education, science and culture institutions, public organizations and diplomatic missions contributed to the integration of new teaching/learning forms and methods into the educational process aimed at training future specialists; international cooperation in the fields of education, science and culture; establishment of a robust platform for exchanging experience and expanding vectors of collaboration during the implementation of the designated education- and culture-related programs, researching in the coming period.

We should say that classroom and extracurricular activities constitute the leading organizational forms of the educational process at our faculty. Their results are evaluated through controlling and monitoring activities: current, modular, and final (semester) types of control (for classroom activities). The organizational forms of the educational process are generalized and presented in Figure one.

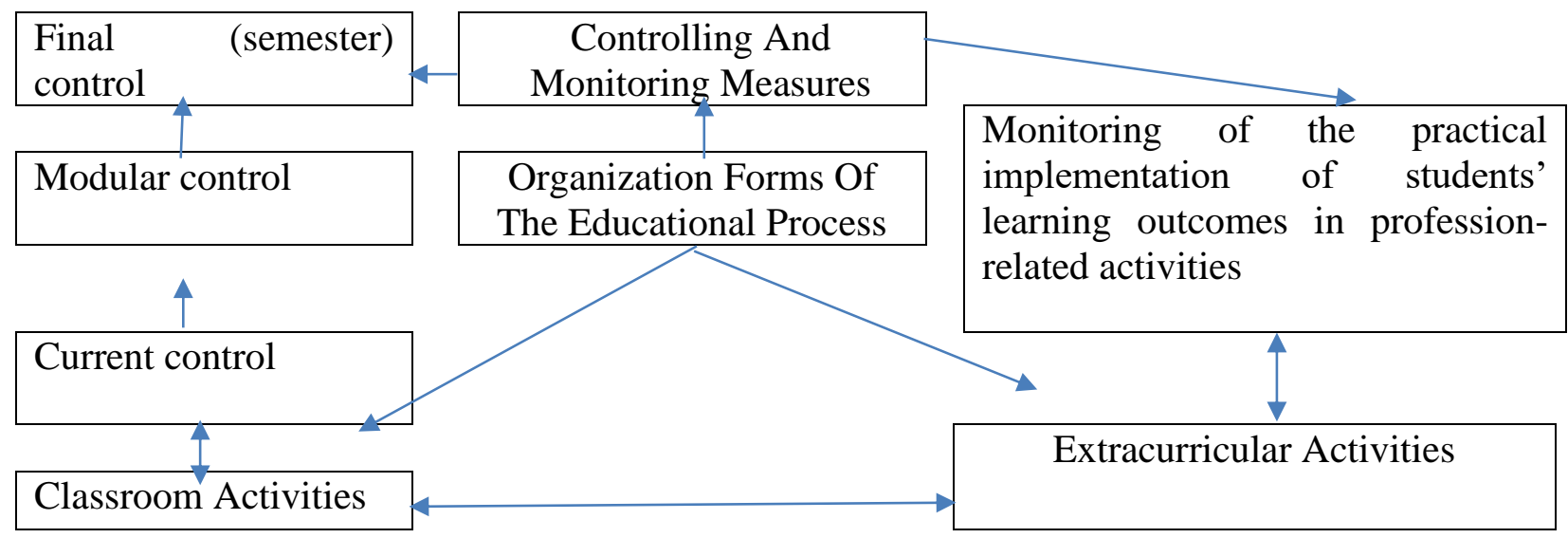

Figure 1. The organizational forms of the educational process at the Faculty of Foreign languages at Ushynsky University

Classroom activities (see Figure two) are provided through combining traditional (lecture, practical, and seminar classes) and modern interactive forms of teaching/learning: interactive lectures (mini-lecture, lecture-press conference, lecture-plenary session, lecture-diapolylogue, conference-workshop); interactive role-playing games (translation workshop, round table discussion, translation ring, exhibitions-fairs of translation ideas, exhibitions of teaching mastery, employers' sessions); interactive workshops with Chinese, American, Turkish, and Korean volunteers. 
Arab World English Journal (AWEJ) Volume 12. Number 3. September 2021

\begin{tabular}{|c|c|c|}
\hline \multicolumn{3}{|c|}{$\begin{array}{r}\text { Classroom Activities } \\
\end{array}$} \\
\hline \multicolumn{3}{|c|}{ Traditional teaching/learning forms } \\
\hline Lect res & Practica classes & Sen inars \\
\hline \multicolumn{3}{|c|}{ Modern interactive te: hing/learning forms } \\
\hline $\begin{array}{l}\text { Interactive pctures: } \\
\text { - mini-lecture; } \\
\text { - lecture-press conference; } \\
\text { - lecture-plenary session; } \\
\text { - lecture-dia-polylogue; } \\
\text { - conference-workshop }\end{array}$ & $\begin{array}{l}\text { Interactive role-playing } \\
\text { games: } \\
\text { - translation workshop; } \\
\text { - round table discussion; } \\
\text { - translation ring; } \\
\text { - exhibitions-fairs of } \\
\text { translation ideas; } \\
\text { - exhibitions of teaching } \\
\text { mastery; } \\
\text { - employers' sessions }\end{array}$ & $\begin{array}{l}\text { Interactive vorkshops - } \\
\text { practical classes } \\
\text { involving Chinese, } \\
\text { American, Turkish, and } \\
\text { Korean volunteers }\end{array}$ \\
\hline
\end{tabular}

Figure 2. Classroom activities at the Faculty of Foreign languages at Ushynsky University

Extracurricular activities differ in a variety of types of profession-oriented educational activities. They include the activities as follows: training, education- and culture-related events, students' independent (self-guided) work, individual research activities, scientific-practical and reporting conferences, work, and language practicing in China, America, Korea, and other countries (see Figure three).

Work practice:

- master classes;

- creativity hours;

- speaking-translating practice with native speakers
Language practice in China, America,

Korea, and other countries

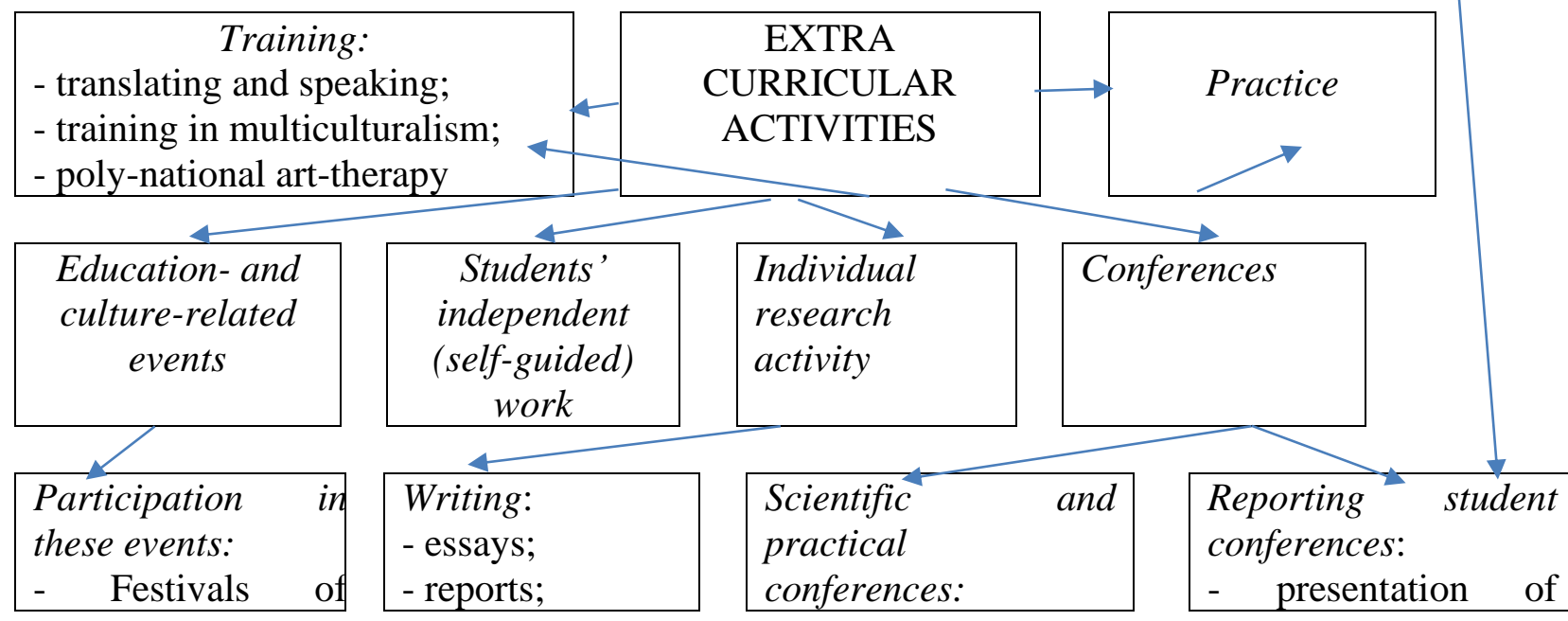




\begin{tabular}{|c|c|c|c|}
\hline $\begin{array}{l}\text { Ukrainian-Turkish } \\
\text { friendship; } \\
\text { - International Day } \\
\text { of Confucius } \\
\text { Institutes; } \\
\text { - Doors Open Day } \\
\text { of Ushynsky } \\
\text { University; } \\
\text { - Chinese/Korean/ } \\
\text { Turkish/English } \\
\text { Bridge; } \\
\text { - Ukrainian/ } \\
\text { Chinese/Turkish/ } \\
\text { Korean } \\
\text { Year, etc.; } \\
\text { - culture-related } \\
\text { (photo) } \\
\text { exhibitions, } \\
\text { concerts; } \\
\text { - demonstration of } \\
\text { traditional } \\
\text { costumes, etc. }\end{array}$ & $\begin{array}{l}\text { - summaries; } \\
\text { - theses; } \\
\text { - articles (co- } \\
\text { authored with the } \\
\text { university } \\
\text { teachers); } \\
\text { - term papers, } \\
\text { etc. }\end{array}$ & $\begin{array}{l}\text { - } \text { oral presentation of } \\
\text { research results } \\
\text { (reports using ICT); } \\
\text { - presentation of } \\
\text { written works } \\
\text { (essays, reports, } \\
\text { summaries, theses, } \\
\text { articles); } \\
\text { - participation in } \\
\text { round table } \\
\text { discussions, debates, } \\
\text { etc.) }\end{array}$ & $\begin{array}{l}\text { learning outcomes in } \\
\text { China, Korea, } \\
\text { America, and other } \\
\text { countries; } \\
\text { - reports "Cultural } \\
\text { Palette"; } \\
\text { - recommendations } \\
\text { on cultural issues of } \\
\text { cross-cultural } \\
\text { communication for } \\
\text { junior students }\end{array}$ \\
\hline
\end{tabular}

Figure 3. Extracurricular activities at the Faculty of Foreign languages at Ushynsky University

The culture-related events held at Ushynsky University facilitate students' motivation to study foreign languages and acquaint them with the culture of the USA, Great Britain, China, Turkey, and Korea. Therefore, we support the idea of Halili and Doçe (2020, p. 1). They "put forward the perspective that the learning process and the consolidation of knowledge through theatre in the pre-university and university system is now a theoretical and a practical reality in almost all the educational systems around the world." To the scholars' mind, theatre is a tremendous "valueforming element that contributes to the students' reading skills, recognition, and reception; it is the technique through which they are taught to work in groups and develop their resources through voice, gestures, mimicry, body language, and textual interpretation" (p. 1). To our great regret, it seems to be impossible to stage theatrical performances at universities today. We are to use alternative teaching/learning techniques (video or online concerts, for example).

On the platform of the Faculty of Foreign Languages, four centers of foreign countries function - Education and Culture Centre "Confucius Institute;" Education, Science, Information and Culture Centers of the Republic of Korea and the State of Israel, the Culture Centre of Turkey. The students participate in the activities initiated by the centers.

While organizing education- and culture-related events, future foreign language teachers and translators get acquainted with the mentality of foreigners and stereotypes of their behavior. Mentality peculiarities of representatives of different countries are manifested through various aspects of culture: musical, choreographic, artistic, food cultural code, etc. 
Musical and choreographic aspects are realized in these events: Festivals of UkrainianTurkish friendship, International Day of Confucius Institutes, Doors Open Day of Ushynsky University, Chinese/Korean/Turkish/English Bridge, Ukrainian/Chinese/Turkish/Korean New Year, etc. (online, offline, in a mixed mode).

The arts of foreign countries are represented during the career guidance work: training in oral Chinese "I greet you...," "Magic colors of body art;" workshop on drawing hieroglyphs and other national symbols on hands, arms, and faces of guests ("Confucius Institute"); master classes in Korean calligraphy, making origami, tangrams, Korean traditional masks, and magnets-hanbok (Education, Science, Information and Culture Centre of the Republic of Korea); language camps aimed at mastering English, Chinese, Turkish, and Korean languages, culture and traditions of China, the USA, Great Britain, Turkey, and the Republic of Korea for the students of Ushynsky University; photo exhibitions; demonstration of traditional costumes; International festivals of languages and cultures, etc. (online, offline, in a mixed mode).

Traditional cuisine plays a vital role in the cultural adaptation of both students and overseas teachers. It includes joint cooking of national cuisine and participation in tea ceremonies. Students and teachers discuss philosophical and cultural aspects and comprehend their essence through the prism of native culture (Popova, 2021). These dishes are popular with our students (see Figure four).

\begin{tabular}{|l|l|}
\hline Name of a dish & Picture \\
\hline Chinese 饺子 / jiăozi (meat dumplings)
\end{tabular}




\begin{tabular}{|l|l|}
\hline - Turkish dolma (vegetable stuffed with a rice-based \\
mixture);
\end{tabular}

Figure 4. Traditional cuisine

Students' self-guided work occupies an essential place in the teaching/learning process. Therefore, we acknowledge the importance of the information searching competence, which is to be developed alongside the culture of working with information and processing it. We agree with the viewpoints of the Ukrainian scholars that there are many unreliable, unverified, obviously fake, and purposefully manipulative texts among the array of information (Markiv, Zarivna, Khymai \& Shalova, 2021). It is evident that there are a lot of destructive sources of data on the Internet. An incompetent searcher can get confused and fail to distinguish if it is the truth or a lie. Under conditions of distance learning, university teachers often give students the assignment to process media material independently and create their texts in the format of essays, reports, summaries, theses, articles (co-authored with the university teachers), term papers, etc.

Our students' opportunity to take part in the programs of academic mobility is another factor to be mentioned. We provide these programs:

- academic mobility programs lasting one semester and one academic year (in higher education institutions in China, the USA, and Korea);

- short-term language practice programs (in higher education institutions in China, the USA, and Korea).

After fulfilling the academic mobility programs, our students present their learning outcomes at reporting conferences and give recommendations on cultural issues of cross-cultural communication to junior students.

As for our university teaching staff, they successfully participate in the international project "Pedagogue," visiting different countries and sharing their experience in the sphere of lingua didactics. Furthermore, they are active partakers of the internship (advanced training) programs "Teaching Chinese and English: current trends," "Fundamentals of profession-oriented training of specialists in Oriental Studies," "Innovations in the system of secondary and higher 
education in China" abroad. And, vice versa, overseas teachers join our internship (advanced training) programs "Theoretical and methodological fundamentals for profession-oriented speech training of foreign translators of Chinese under conditions of university education" and "Development of linguistic and cultural competence of university teaching staff," which helps them adapt to the local community.

\section{Discussion}

Through the analysis of the interview results, the contents of the (extra)curricular culture-related activities, and academic mobility programs, the findings demonstrate that intercultural activities contribute both to the students' academic success and internationalization of the faculty functioning through diverse aspects of culture: musical, choreographic, artistic, food cultural code, etc., which is manifested in the additional students" learning outcomes in English, Chinese, Turkish, and Korean (see Table one).

Table 1. Additional students" learning outcomes in English, Chinese, Turkish, and Korean

\begin{tabular}{|c|c|c|}
\hline Knowledge (awareness) & $\begin{array}{c}\text { Practical experience } \\
\text { (abilities) }\end{array}$ & Skills \\
\hline $\begin{array}{l}\text { - background knowledge of } \\
\text { national traditions, customs, } \\
\text { norms, moral and cultural } \\
\text { values of China, Ukraine, } \\
\text { Great Britain (the USA), } \\
\text { including culture-related } \\
\text { vocabulary minimum; } \\
\text { - awareness of economic, } \\
\text { social, and political } \\
\text { peculiarities of the countries } \\
\text { mentioned above; } \\
\text { - awareness of etic and } \\
\text { aesthetic aspects regarding } \\
\text { verbal and non-verbal } \\
\text { behavior of native speakers in } \\
\text { compliance within certain } \\
\text { intercultural communicative } \\
\text { circumstances; } \\
\text { - navigation in the specificity } \\
\text { of nation-related peculiarities } \\
\text { of mother tongue and target } \\
\text { languages). }\end{array}$ & $\begin{array}{l}\text { - practical experience in the } \\
\text { use of background knowledge } \\
\text { in cross-cultural } \\
\text { communication; } \\
\text { - abilities to analyze } \\
\text { functioning mechanisms of } \\
\text { economic, social and political } \\
\text { institutions and productive } \\
\text { cooperation of partner } \\
\text { countries (China, Ukraine, } \\
\text { Great Britain / the USA) and } \\
\text { colleagues within the process } \\
\text { of profession-related } \\
\text { activities; practical experience in the } \\
\text { - prate } \\
\text { identification and adequate } \\
\text { decoding of unseen } \\
\text { sociocultural, economic and } \\
\text { political aspects of cross- } \\
\text { cultural communication; } \\
\text { - practical experience in } \\
\text { demonstrating an adequate } \\
\text { flexible behavior model in the } \\
\text { dialogue of cultures in } \\
\text { compliance with moral and } \\
\text { aesthetic norms, typical of } \\
\text { countries representing the } \\
\text { source and target languages; } \\
\text { - abilities to analyze linguistic }\end{array}$ & 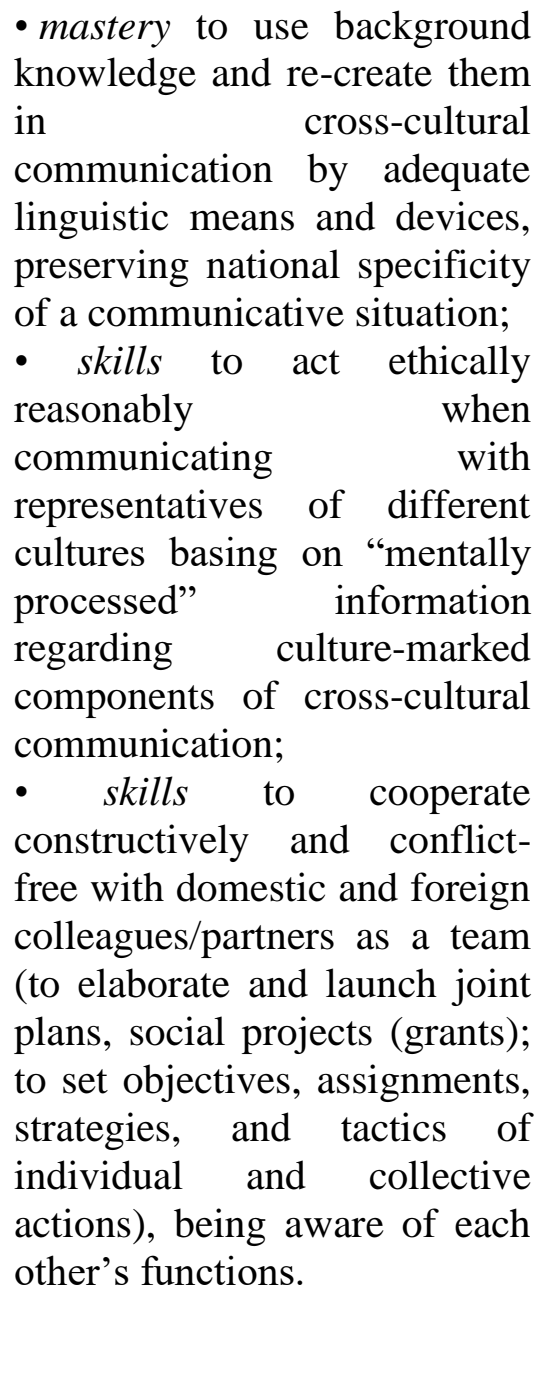 \\
\hline
\end{tabular}




features of interlocutors'
culture-marked directives to
select adequate translation and
communication means.

Thus, considering the content of the internationalization of the teaching/learning process at the Faculty of Foreign Languages at Ushynsky University, we would like to share some recommendations for Chinese, English, Korean, and Turkish online, offline, and mixed classroom activities alongside extracurricular intercultural activities.

The profession-oriented training of the future translators and teachers of foreign languages under current conditions has all grounds to formulate these recommendations:

- It is expedient to widen the spheres dealing with the internationalization of education and involve the potential of the education and culture centers of foreign countries.

- Education-based intercultural extracurricular activities facilitate students' academic acquisitions. So, it is worth holding culture-related events in diverse modes: online, offline, and a mixed one.

- To improve students' learning outcomes in English, Chinese, Turkish, and Korean, it is rational to give these teaching/learning suggestions:

- to organize students' self-guided work on culture-related issues and let them demonstrate (present) their results to the audience;

- to provide students with optimal conditions for interacting with native speakers in terms of organizing culture-related events and improving intercultural communication;

- to encourage students to participate in the programs of academic mobility (one semester, one academic year, and short-term programs (two weeks).

Thus, keeping to the recommendations mentioned above might improve students' learning outcomes in compliance with the designated profession-oriented educational programs and increase their learning acquisitions.

\section{Conclusion}

This paper has traced students' learning outcomes in English, Chinese, Turkish, and Korean. The authors acquainted the teaching audience with the issues related to implementing intercultural events into teaching foreign languages (English, Chinese, Turkish, and Korean) to Ukrainian university students. Some Bachelor Educational Programs targeted to the future translators and teachers of foreign languages have been analyzed, which made us assume that extracurricular culture-related activities contribute to our students' academic success, acquisition of additional knowledge, abilities, and skills, to be more precise, independently from the programs' requirements and content. It has been proved that the integration of international work and methodological tools of teaching foreign languages to Ukrainian students in diverse modes (online, offline, in a mixed mode) can contribute to their academic success. We have found out some teaching/learning suggestions which could facilitate students' learning outcomes in English, Chinese, Turkish, and Korean; (students' self-guided work on culture-related issues; interaction with native speakers in terms of organizing culture-related events; participation in the programs of academic mobility; online/offline demonstrations of students' learning outcomes). 
Finally, we may resume that this paper sets a background for further development of a system of activities and tasks under modern conditions, contributing to students' professionoriented competences.

\begin{abstract}
About the Authors:
Dr. TETIANA KOROLOVA, Doctor of Philological Sciences, is a Full Professor. She has researched and published in these areas: experimental studies of linguistic characteristics and modeling of the contemporary discourse structure; methodological background for training future translators/interpreters; Translation Studies (the variability of strategies and tactics while translating different types of discourse, discourse analysis, adequacy of translation); General Linguistics; Contrastive Linguistics, etc. ORCid: https:// orcid.org/0000-0003-3441-196X
\end{abstract}

Dr. OLEKSANDRA POPOVA, Doctor of Pedagogical Sciences, is a Full Professor. Her research interests include teaching English and Chinese to future translators/interpreters (teaching tools for developing skills in listening comprehension, speaking, reading, and writing); Translation Studies (discourse analysis, adequacy of translation, translatorial competence, tactic and strategic issues of translation); General Linguistics; Comparative Linguistics, etc.

ORCid: https:// orcid.org/0000-0002-6244-5473

\title{
References
}

Al Ghafri, M., Audeh, Y., \& Al-Gadallah, M. (2019) Teaching to Test or Communicate. Arab World English Journal, 10 (2). 225-241. DOI: https://dx.doi.org/10.24093/awej/vol10no2.18.

Andayani \& Gilang. (2020). The Understanding of Local Cultural Treasures on Foreign Students in Indonesian Language Learning. Universal Journal of Educational Research, 8(9), 4113-4121. DOI: 10.13189/ujer.2020.080937.

Bagui, H., \& Adder, F. Z. (2020). Promoting Students' Intercultural Communicative Competence through English Literary Texts: Students' Attitudes and Teachers' Challenges. Arab World English Journal, 11 (2) 85-93.

DOI: https://dx.doi.org/10.24093/awej/vol11no2.7

Bouslama, A., \& Benaissi, F. B. (2018). Intercultural Competence in ELT Contexts: A Study of EFL Teachers' Perceptions. Arab World English Journal, 9 (4). 122-135. DOI: https://dx.doi.org/10.24093/awej/vol9no4.8.

Byram, M. \& Esarte-Sarries, V. (1991). Investigating Cultural Studies in Foreign Language Teaching: A Bookfor Teachers. Clevedon, United Kingdom: Multilingual Matters, Ltd.

Byram, M. \& Morgan, C. (1994). Teaching and Learning Language and Culture. Clevedon: Multilingual Matters.

Byram, M. (1997). Teaching and assessing intercultural communicative competence. Clevedon: Multilingual Matters.

Chekal, H. S., Palii, O. A., Potapenko S. I. \& Andriiko, I. F. (2010). Methods of Teaching Foreign Languages in Secondary Schools. Kyiv: Lenvit.

Common European Framework of Reference for Languages: Learning, Teaching, Assessment. (2001). Strasbourg: Cambridge University Press. Retrieved from https://rm.coe.int/16802fc1bf. 
Derik, I. M., Savchenko, Y. Y., \& Shapoval, A. S. (2020). The Educational Profession-targeted Program "Translation (major - English, minor - Chinese)". Odesa: South Ukrainian National Pedagogical University named after K. D. Ushynsky.

Farahmandian, H., \& Shao, L. (2020). Sociocultural Studies via CDA in Native Son (1939). Arab World English Journal, 11 (1). 389-398. DOI: https://dx.doi.org/10.24093/awej/vol11no1.26.

Fernández, D. M. \& Pérez Cañado, M. L. (2012). CLIL Teacher Training. In J. D. M. Agudo (ed.), Teaching and Learning English through Bilingual Education (pp. 181-212). Cambridge: Cambridge Scholars Publishing.

Fox, R., \& Diaz-Greenberg, R. (2016). Culture, Multiculturalism, and Foreign Language Standards in U.S. Teacher Preparation Programs: Toward a discourse of dissonance. European Journal of Teacher Education, XXIX (3), 401-422.

Gerkerova, O. M., Zaitseva, K. I., \& Negrivoda, O. O. (2020). The educational professiontargeted program "Secondary Education (Language and Literature (English)": Bachelor Level. Odesa: South Ukrainian National Pedagogical University named after K. D. Ushynsky.

God, Y.T., \& Zhang, H. (2019). Intercultural challenges, intracultural practices: how Chinese and Australian students understand and experience intercultural communication at an Australian university. High Education, 78, 305-322. https://doi.org/10.1007/s10734-0180344-0.

Halili, E. G., \& Doçe E. (2020). Drama Club: A Creative, Performing, Multidisciplinary and Cultural Laboratory in Tirana University. Universal Journal of Educational Research. 8(10). P. 4500-4506. DOI: 10.13189/ujer.2020.081017.

Larzén, E. (2005). In pursuit of an intercultural dimension in EFL-teaching: Exploring cognitions among Finland-Swedish comprehensive school teachers. Abo: Abo Akademi University Press.

Merriam-Webster's Thesaurus (1828). Retrieved from https://www.merriamwebster.com/thesaurus.

Markiv, O., Zarivna, O., Khymai, N., \& Shalova, N. (2021). Formation of the Culture of Working with Information in the Conditions of Distance Learning During the Covid-19 Pandemic. Arab World English Journal (AWEJ), Special Issue on Covid 19 Challenges (1). 318-333. DOI: https://dx.doi.org/10.24093/awej/covid.24.

Ministry of Economy, Trade and Agriculture Development of Ukraine (2020). The Professionrelated Standard for the Professions: "Primary School Teacher at General Secondary School," "Teachers of General Secondary School," "Primary School Teacher (based on the junior specialist diploma).” Kyiv: Ministry of Economy, Trade and Agriculture Development of Ukraine.

Ministry of Education and Science of Ukraine (2019). Higher education standard of Ukraine: First (Bachelor of Arts) Level, 03 "The Humanities, " 035 "Philology." Kyiv: Ministry of Education and Science of Ukraine.

Ministry of Education and Science of Ukraine (2019). Higher education standard of Ukraine: Second (Master) Level, 03 “The Humanities," 035 "Philology. ” Kyiv: Ministry of Education and Science of Ukraine.

Naryatmojo, D. L. (2019). Internalization of the Concept of Local Wisdom for Students in the Listening Class. Arab World English Journal, 10(1). 382-394. DOI: https://dx.doi.org/10.24093/awej/vol10no1.31. 
Nikolayeva, S. (Ed.). (2002). Methods of Teaching Foreign Languages in Establishments of Secondary Education. Kyiv: Lenvit.

Nikolayeva, Zh. (2004). The Basics of Communication Theory. Ulan-Ude: VSGTU.

Oskina, N. O., Stryga, E. V., Anhelovska K. V., \& Mazurina, Yu. O. (2020). The educational profession-targeted program "Secondary Education (Language and Literature (Chinese, English)”: Bachelor Level. Odesa: South Ukrainian National Pedagogical University named after K. D. Ushynsky.

Oxford, R. (1990). Language Learning Strategies: What every teacher should know. New York: Newbury House Publishers.

Pak, A., Mulyk, K. O., Myrkovich, I. L., \& Iordanova, D. M. (2021). The educational profession-targeted program "Secondary Education (Language and Literature (Korean, English)”: Bachelor Level. Odesa: South Ukrainian National Pedagogical University named after K. D. Ushynsky.

Peeters, B. (2015). Language and culture values: adventures in applied ethnolinguistics. International Journal of Language and Culture. II.(2), 133-141.

Popova O. (2016). Profession-oriented speech training of the future translators of Chinese under conditions of university education: theoretical issues. Odesa: South Ukrainian National Pedagogical University named after K. D. Ushynsky; Odesa municipal Publishing House.

Popova, A. (2021). Interiorisation of Educational Process as a Cornerstone of Academic Success. Modern vectors of science and education development in China and Ukraine (中国与乌 克兰科学及教育前沿研究), (7). 103-110. Odesa: South Ukrainian National Pedagogical University named after K. D. Ushynsky, Harbin: Harbin Engineering University.

Popova, O. V., Korolova, N. V., \& Stoianova, T. V. (2020). The educational profession-targeted program "Translation (major - Chinese, minor - English)": Bachelor Level. Odesa: South Ukrainian National Pedagogical University named after K. D. Ushynsky.

Prodromou, L. (2012). What culture? Which culture? Cross-cultural factors in language learning. English Language Teaching. LXVI.(1), 39-50.

Shin, J, Zohreh, R. E., \& Chen, W.C. (2011). Presentation of local and international culture in current international English-language teaching textbooks. Language, Culture and Curriculum. XXIV(3), 253-268.

Veettil, R. P., Binu, P.M., \& Karthikeyan, J. (2020). Language Maintenance and Language Shift among Keralites in Oman. Arab World English Journal, 11 (4) 319-327. DOI: https://dx.doi.org/10.24093/awej/vol11no4.21

Vez, J. M. (2011). La investigación en didáctica de las lenguas extranjeras. en Educación Siglo xxi, 29(1), 81-108. Retrieved from: http://revistas.um.es/educatio/article/view/119881/112861[Consulta: junio de 2019].

Yumrukuz, A. A., Yablonska, T. M., Avramenko, B. V., \& Iordanova, D. M. (2020). The educational profession-targeted program "Secondary Education (Language and Literature (Turkish, English)": Bachelor Level. Odesa: South Ukrainian National Pedagogical University named after K. D. Ushynsky. 